\title{
Incidence and Causes of Liver Dysfunction in Neonatal Intensive Care Unit in Benha Children Hospital
}

\author{
S.A.Yassein ${ }^{1}$, E.H.Assar ${ }^{1}$, Y.M.Ismail ${ }^{2}$, A.E.Mahmoud ${ }^{1}$ \\ ${ }^{1}$ PediatricsDept,Faculty of Medicine, Benha Univ., Benha, Egypt \\ ${ }^{2}$ Clinical Pathology Dept., Faculty of Medicine, Benha Univ., Benha, Egypt \\ E-Mail:Shymaa@gmail.com
}

\begin{abstract}
Liver dysfunction plays a significant role in the Intensive Care Unit [ICU] patients' morbidity and mortality.Metabolic, hemodynamic and incendiary components contribute in liver harm. Hemorrhagic stun. The examination planned to evaluate the rate of liver brokenness in neonatal emergency unit patients in pediatric office. This investigation was planned examination which led on 150 cases in Neonatal emergency unit Benha youngsters clinic which is a shut multidisciplinary optional NICU during the examination which was a half year [1/7/2018 - 31/12/2018]. All included patients were exposed to the accompanying: History taking, assessment and Laboratory examinations included Liver capacity tests including: Patients with hepatic friendship were characterized as the individuals who had any raised transaminases or cholestatic jaundice or hepatomegly dependent on clinical assessment and research center outcomes. Liver brokenness happened in 45 [30\%] of the examined gathering. There were no factually critical distinction between Patients with hepatic warmth and Patients without hepatic fondness with respect to Sex. The death rate among cases was $14 \%$. There was no factually critical distinction between Patients with hepatic fondness and Patients without hepatic love with respect to result. Liver brokenness are normal in NICU speaking to around 33\% of cases. Key words: Liver dysfunction- neonates intensive care unit- incidence.
\end{abstract}

\section{Introduction}

Liver brokenness assumes a huge function in the Intensive Care Unit [ICU] patients' bleakness and mortality. Metabolic, hemodynamic and incendiary elements contribute in liver harm. Hemorrhagic stun, septic stun, various organ brokenness, intense respiratory brokenness, metabolic problems, myocardial brokenness, contamination from hepatitis infection, and remedial estimates, for example, blood bonding, parenteral nourishment, immunosuppresion, and medications are totally perceived as possible clinical circumstances on the grounds of which liver brokenness creates [1].

The liver endures the results of stun or sepsisprompting conditions, which change hepatic flow boundaries, oxygen flexibly and provocative reactions at the cell level. Additionally, the liver is an orchestrator of metabolic plans which advance the freedom and creation of provocative go betweens, the searching of microbes, and the blend of intense stage proteins. This equilibrium characterizes the stage whereupon the disorder of "stun liver" creates. Ischemic hepatitis creates from stun and is portrayed by raised plasma aminotransferase focuses. 'ICU jaundice' develops later in basic ailment, for the most part in patients with injury and sepsis. The ordinarily detailed biochemical anomaly is formed hyperbilirubinaemia. The clinical setting proposes that hepatic ischemia and hepatotoxic activities of incendiary go betweens are the primary aetiological components [2]

Despite the fact that conclusions of aminotransferases, coagulation contemplates, glucose, lactate and bilirubin can identify hepatic injury, they just halfway mirror the fundamental pathophysiological components. Both the presence and level of jaundice are related with expanded mortality in various non hepatic ICU illnesses [3].
The examination intended to survey the frequency of liver brokenness in neonatal emergency unit patients in pediatric department.

\section{Patients and methods \\ Patients}

This study was prospective study which conducted on 150 cases in Neonatal intensive care unit of Benha children hospital which is a closed multidisciplinary secondary NICU during the study which was 6 months [1/7/2018-31/12/2018].

The study was approved by the ethical committee of the hospital. Informed consent obtained from the parents of all babies enrolled in the study.

\section{Patients included}

All patients admitted to Neonatal intensive care unit of Benha during the study period which was 6 months [1/7/2018 - 31/12/2018].

\section{Exclusion criteria}

- Age above 1 month.

- Discharge in less than 4 hours after admission.

- Discharge or death before liver functional state is accurately assessed.

\subsection{Methods}

All included patients were exposed to the accompanying:

\section{History taking}

- Prenatal history; particularly maternal disease, history of premature births and connection.

- Natal history; Mode and area of conveyance, pushing on the presence or nonattendance of blocked work, and the term of untimely break of films if present. 
- Post natal history; Name, time of beginning, period of introduction, sex, gestational age, birth weight and sign of affirmation.

\section{Clinical assessment}

\section{General assessment}

- Anthropometric measures: Weight, length and head boundary

- Complete general assessment with exceptional accentuation on dysmorphic highlights

- Detection of indications of sepsis as skin mottling, sclerema and poor neonatal reflexes.

- Detection of indications of liver brokenness as jaundice, edema, ecchymotic patches and palmar erythema.

- Foundational assessment:

- Detailed stomach assessment for discovery of organomegaly or ascites.

- Other frameworks assessment to reject reasons for optional hepatic warmth as cardiovascular, hematological, endocrinal and hereditary causes.

- Lab examinations:

- Liver work tests including: all out and direct serum bilirubin, transaminases [AST and ALT], basic phosphatase [ALP], serum egg whites, prothrombin time $[\mathrm{PT}]$.

\section{Result}

- Duration of confirmation, last finding if accessible and result [mortality, settled or released with sequelae] were accounted for.

- Patients with hepatic fondness were characterized as the individuals who had any raised transaminases or cholestatic jaundice or hepatomegly dependent on clinical assessment and research center outcomes [4].

\subsection{Statistical analysis}

The collected data were tabulated and analyzed using SPSS version 16 software [SpssInc, Chicago, ILL Company]. Categorical data were presented as number and percentages. Chi square test $\left[\mathrm{X}^{2}\right]$, or Fisher's exact test [FET] were used to analyze categorical variables. Quantitative data were tested for normality using KolomogrovSmirnove test assuming normality at $\mathrm{P}>0.05$. Quantitative data were expressed as mean \pm standard deviation, median and range. Student " $t$ " test was used to analyze normally distributed variables among 2 independent groups, or Man Whitney U test for nonparametric ones. The accepted level of significance in this work was stated at $0.05[\mathrm{P}<0.05$ was considered significant].

$\mathrm{P}$ value $>0.05$ is non-significant $[\mathrm{N}-\mathrm{S}]$.

$\mathrm{P}<0.05$ is significant $[\mathrm{S}]$.

\subsection{Results}

This table shows that the Mean of G. Age [35.24 \pm 3.065], age on admission [7.27 \pm 6.771], weight [2432.20 \pm 861.888 ], the percentage of female [45.3\%], male [54.7\%], CS [80.7\%], NVD [19.3\%] Table (1).

This table showed that the mortality rate among cases was $14 \%$ Table (2).

This Table shows that the percentage of Patients with hepatic affection [30\%], Patients without hepatic affection [70\%] Table (3).

There were no statistically significant difference between Patients with hepatic affection and Patients without hepatic affection regarding age on admission, weight, Sex, Mode of delivery

There was statistically significant increase in G. Age among Patients with hepatic affection than Patients without hepatic affection Table (4).

There was no statistically significant difference between Patients with hepatic affection and Patients without hepatic affection regarding outcome Table (5).

There were statistically significant increase in Total bilirubin, direct bilirubin among Patients with hepatic affection than Patients without hepatic affection Table (6).

There were statistically significant increase in ALT and AST among Patients with hepatic affection than Patients without hepatic affection Table (7).

Table (1)Demographic data of the studied cases.

\begin{tabular}{lccc}
\hline & Rang & Mean \pm SD \\
\hline G. Age & $27-40$ & $35.24 \pm 3.065$ \\
Age on admission & & $1-28$ & $7.27 \pm 6.771$ \\
Weight & & $750-4000$ & $2432.20 \pm 861.888$ \\
& & No. & $\%$ \\
Sex & 68 & 45.3 \\
& female & 82 & 54.7 \\
Mode of delivery & male & 121 & 80.7 \\
& CS & 29 & 19.3 \\
\hline
\end{tabular}

Table (2)Outcome of the studied cases.

\begin{tabular}{llll}
\hline & & No. & \% \\
\hline Outcome & Alive & 129 & 86.0 \\
& Dead & 21 & 14.0 \\
\hline
\end{tabular}


Table (3)Hepatic affection of the studied cases.

\begin{tabular}{lccc}
\hline & & No. & $\%$ \\
\hline Cases & Patients with hepatic affection & 45 & 30.0 \\
& Patients without hepatic affection & 105 & 70.0 \\
\hline
\end{tabular}

Table (4) Comparison between Patients with hepatic affection and Patients without hepatic affection regarding Demographic data.

\begin{tabular}{|c|c|c|c|c|c|c|}
\hline & & & $\begin{array}{c}\text { Patients with hepatic } \\
\text { affection }\end{array}$ & $\begin{array}{l}\text { Patients without } \\
\text { hepatic affection }\end{array}$ & t.test & $\begin{array}{c}\text { P. } \\
\text { value }\end{array}$ \\
\hline G. Age & Mean \pm SD & & $35.98 \pm 2.86$ & $34.92 \pm 3.12$ & 1.948 & 0.04 \\
\hline age on admission & Mean \pm SD & & $8.67 \pm 6.57$ & $6.67 \pm 6.79$ & 1.668 & 0.097 \\
\hline weight & Mean \pm SD & & $2502.89 \pm 785.57$ & $2401.90 \pm 894.48$ & 0.656 & 0.513 \\
\hline Sex & Female & $\begin{array}{c}\text { No. } \\
\%\end{array}$ & $\begin{array}{c}22 \\
48.9 \%\end{array}$ & $\begin{array}{c}46 \\
43.8 \%\end{array}$ & $\begin{array}{l}\mathbf{X}^{\mathbf{2}} \\
0.328\end{array}$ & 0.567 \\
\hline & Male & $\begin{array}{c}\text { No. } \\
\%\end{array}$ & $\begin{array}{c}23 \\
51.1 \%\end{array}$ & $\begin{array}{c}59 \\
56.2 \%\end{array}$ & & \\
\hline Mode of delivery & $\mathrm{CS}$ & $\begin{array}{c}\text { No. } \\
\%\end{array}$ & $\begin{array}{c}38 \\
84.4 \%\end{array}$ & $\begin{array}{c}83 \\
79.0 \%\end{array}$ & $\begin{array}{l}\mathbf{X}^{2} \\
0.588\end{array}$ & 0.443 \\
\hline & NVD & $\begin{array}{c}\text { No. } \\
\%\end{array}$ & $\begin{array}{c}7 \\
15.6 \%\end{array}$ & $\begin{array}{c}22 \\
21.0 \%\end{array}$ & & \\
\hline
\end{tabular}

Table (5)Comparison between Patients with hepatic affection and Patients without hepatic affection regarding outcome.

\begin{tabular}{lcccccc}
\hline & & $\begin{array}{c}\text { Patients with } \\
\text { hepatic affection }\end{array}$ & $\begin{array}{c}\text { Patients without } \\
\text { hepatic affection }\end{array}$ & $\begin{array}{c}\mathbf{X}^{2} \\
\text {.test }\end{array}$ & $\begin{array}{c}\text { P. } \\
\text { value }\end{array}$ \\
\hline Outcome & Alive & No. & 37 & 92 & 0.76 & 0.38 \\
& & $\%$ & $82.2 \%$ & $87.6 \%$ & & \\
& Dead & No. & 8 & 13 & & \\
\hline
\end{tabular}

Table (6)Comparison between Patients with hepatic affection and Patients without hepatic affection regarding Total bilirubin, direct bilirubin.

\begin{tabular}{|c|c|c|c|c|c|}
\hline & & $\begin{array}{c}\text { Patients with hepatic } \\
\text { affection }\end{array}$ & $\begin{array}{l}\text { Patients without } \\
\text { hepatic affection }\end{array}$ & t.test & P. value \\
\hline $\begin{array}{l}\text { Total } \\
\text { bilirubin }\end{array}$ & Mean \pm SD & $4.5 \pm 1.3$ & $.5 \pm .01$ & 6.1 & .000 \\
\hline $\begin{array}{l}\text { Direct } \\
\text { bilirubin }\end{array}$ & Mean \pm SD & $.9 \pm .1$ & $.02 \pm .001$ & 15.9 & .000 \\
\hline
\end{tabular}

Table (7)Comparison between Patients with hepatic affection and Patients without hepatic affection regarding ALT and AST.

\begin{tabular}{lccccc}
\hline & $\begin{array}{c}\text { Patients with hepatic } \\
\text { affection }\end{array}$ & $\begin{array}{c}\text { Patients without } \\
\text { hepatic affection }\end{array}$ & t.test & P. value \\
\hline ALT & Mean \pm SD & $65 \pm 20.7$ & $10.2 \pm 1.8$ & 2.8 & .000 \\
AST & Mean \pm SD & $62 \pm 19.4$ & $10.1 \pm 1.3$ & 1.7 & .000 \\
\hline
\end{tabular}

\section{Discussion}

This study was imminent examination which led on 150 cases in Neonatal emergency unit Benha kids clinic which is a shut multidisciplinary optional NICU during the investigation which was a half year $[1 / 7 / 2018-$ 31/12/2018].

This examination was led on 150 child with mean of G. Age [35.24 \pm 3.065$]$, age on confirmation [7.27 \pm
$6.771]$, weight [2432.20 \pm 861.888$]$, the level of female [45.3\%].

This examination demonstrated that, liver brokenness happened in 45 [30\%] of the considered gathering.

A few past examinations have additionally distinguished these elements as a significant causal factor in hepatic brokenness. Such brokenness might be clarified by the hypothesis of hepatic cell uprightness and bile emission measures which are hindered by hepatic hypoxia-ischemia. Be that as it may, it is believed to be of multifactorial cause. Liver injury in 
such cases is by all accounts a piece of multisystem organ contribution. The seriousness and determination of liver injury rely upon hidden issues, and the liver harm is generally reversible by adjustment of circulatory issue. In any case, standardization of liver brokenness may take a while [2].

This concurs with Tufano et al., [5] study, which included 1289 youngsters. They found that, 27 had liver brokenness, a multifactorial premise [prematurity, asphyxia, parenteral sustenance, chromosomal problems, diseases, sepsis, Rhalloimmunization].

Hypoxic hepatic injury signifies injury caused to hepatocytes by hypoxia. It is portrayed by abrupt ascent in serum level of hepatic catalysts, beginning not long after hypoxic affronts, arriving at a top following 1-3 days of injury and getting back to ordinary levels following 7-10 days [6].

This lower than [3] their examination was led to decide the predominance, example, and course of hepatobiliary brokenness in youngsters, and to assess its impact on the endurance and development. They found that, hepatobiliary brokenness was found in 83 [54.2\%] subjects.

Diminished liver brokenness in our examination than Khalil et al., [3] might be because of they incorporated the entirety of the youngsters with clinical doubt of sepsis or a positive sepsis screen [m-erythrocyte sedimentation rate, C-responsive protein, absolute leukocyte check, band exclude [any 2 positive of 4]] that admitted to the neonatal emergency unit the emergency clinic and venous blood culture was finished.

In the current examination, hypoxia happened in [11\%] in the gathering with hepatic friendship.

This concurs with Chhavi et al., [7] who discovered a few newborn children with birth asphyxia and hypoxic endure hepatic injury,

This examination demonstrated that, there were no measurably huge distinction between Patients with hepatic warmth and Patients without hepatic friendship in regards to Sex.

This outcome was steady with discoveries in Croatia [8], Iran [9], and Egypt [10].

In our examination, there was no measurably critical distinction between Patients with hepatic fondness and Patients without hepatic warmth in regards to result.

Current outcomes were predictable with that of Khalil et al., [3] study, who discovered hepatobiliary brokenness was seen all the more normally in those children who endure. This was factually critical [P1/40.001].

This investigation indicated that, there were factually critical expansion in Total bilirubin, direct bilirubin, ALT and AST among Patients with hepatic love than Patients without hepatic friendship.

These discoveries were similar with the aftereffect of study Liu et al. [11] in their examination, who investigated the danger factors influencing guess of liver brokenness in babies and recognized a straight certain connection between's the degrees of serum complete bilirubin, direct bilirubin, bile corrosive, ALT and AST and the term of hepatic friendship. They found that, all out bilirubin, direct bilirubin, ALT and AST among Patients with hepatic friendship than Patients without hepatic affection.

\section{Conclusion}

Liver brokenness are regular in NICU speaking to around $33 \%$ of cases.

\section{References}

[1] M.Kluge, F. Tacke,. Liver impairment in critical illness and sepsis: the dawn of new biomarkers?. Annals of translational medicine, Vol.7, PP.S258,2019.

[2] M.Ş. İpek, M. Aydın, A. Zencıroğlu, Conjugated hyperbilirubinemia in the neonatal intensive care unit. Turk J Gastroenterol,Vol.24, PP.406-414,2013.

[3] S. Khalil, D. Shah, M.M. Faridi, Prevalence and outcome of hepatobiliary dysfunction in neonatal septicaemia. J PediatrGastroenterolNutr,Vol. 54, PP.218-222,2012.

[4] F. Suchy, S. Sundaram, B.Shneider Familial hepatocellular cholestasis. In: Liver disease in children. Edition 4. Suchy F, Sokol R, Balistreri W [eds]. Cambridge university press,Vol.35, PP.199,2014.

[5] M. Tufano, E. Nicastro, P. Giliberti, Cholestasis in neonatal intensive care unit: incidence, aetiology and management. Acta Paediatr,Vol.98, PP.1756$1761,2009$.

[6] M. Feldman, S.F. Lawrence, J.B. Lawrence,Sleisenger and Fordtran gastrointestinal and liver disease: pathophysiology, diagnosis, management. $9^{\text {th }}$ ed. Philadelphia: Saunders Elsevier,Vol.25, PP.413-425,2010.

[7] N. Chhavi, K. Zutshi, N.K. Singh, Serum liver enzyme pattern in birth asphyxia associated liver injury. Pediartigastroentrolhepatolnutr,Vol. 17, PP.162-169,2014.

[8] I.Mesić, V.Milas, M.Medimurec, Unconjugated pathological jaundice in newborns. Collegium Antropologicum ,Vol.38,PP.173-1782014.

[9] Z. Kavehmanesh, N. E. Mohammadieh, A. A. K. Zarchi, Prevalence of readmission for hyperbilirubinemia in healthy newborns. Iranian J.,Pediatrics,Vol.18,PP.130-136,2008.

[10]T. Abdel-Aziz, N. Azab, M. Odah, Factors and assays identifying babies at riskto develop significant hyperbilirubinemia. International J.,Innovative Research in Science, Engineering and Technology, Vol.3 , PP.9804-9809,2014.

[11]P. Liu, L. Guo, L. Huang, Analysis of factors affecting the prognosis of neonatal cholestasis. Int $\mathbf{J}$ ClinExpMed,Vol. 8, PP.8005-8009,2015. 